\title{
Oral Papillomatosis in a Dog and its Therapy with Taurolidine
}

\author{
H.S. BIRICIK ${ }^{1}$, M. CABALAR ${ }^{2}$, M.Y. GULBAHAR ${ }^{3}$ \\ ${ }^{1}$ Department of Surgery, Faculty of Veterinary Medicine, Harran University, Sanliurfa, Turkey \\ ${ }^{2}$ Department of Virology, Faculty of Veterinary Medicine, Harran University, Sanliurfa, Turkey \\ ${ }^{3}$ Department of Pathology, Faculty of Veterinary Medicine, Ondokuz Mayis University, Samsun, Turkey
}

Received August 17, 2007

Accepted March 13, 2008

\begin{abstract}
Biricik H.S., M. Cabalar, M.Y. Gulbahar: Oral Papillomatosis in a Dog and its Therapy with Taurolidine. Acta Vet. Brno 2008, 77: 373-375.

The efficacy of taurolidine on the treatment of oral papillomatosis in a 1-year-old Turkish Kangal dog was evaluated. Diagnosis of the papillomatosis was based on clinical signs, histopathological and immunohistochemical examinations. The dog received $45 \mathrm{mg} / \mathrm{kg}$ taurolidine intravenously every 3 days. Regression of papillomas started to be observed after the beginning of treatment, and complete resolution occurred after the fifth application.
\end{abstract}

Papillomatosis, taurolidine, dog

Oral papillomatosis is seen more commonly in young dogs, and warts usually begin on the lips and may spread to the buccal mucosa, tongue, palate, and pharynx. It is characterized by multiple papillomas in the oral cavity. The lesions occasionally become extensive, requiring veterinary attention (Bredal et al. 1996; Fenner et al. 1993). Furthermore, with the increasing number of papillomas, food consumption may become a problem.

Taurolidine is a novel antimicrobial agent for local or parenteral use. It has a unique spectrum of antimicrobial activity, including gram negative and positive bacteria and fungi (Blenkharn 1988). It has been used extensively for its antimicrobial and antiendotoxemic properties, particularly in peritonitis (McCourt et al. 2000). Taurolidine also appears to possess immunoregulatory properties, reducing tumour growth and spread (Nici et al. 2004).

Experimental studies proved that the systemic administration of taurolidine solution is well tolerated (Johnston et al. 1993; Torres-Viera et al. 2000). According to veterinary literature, no research was conducted to establish whether systemic administration of taurolidine influences oral papillomatosis. We hypothesized that taurolidine may have an effect on oral papillomatosis. Our aim was to examine the therapeutic effectiveness of taurolidine against canine oral papillomatosis.

\section{Materials and Methods}

A 1-year-old Turkish Kangal dog was presented with severe papillomatous growths protruding from the oral mucous membranes (Plate X, Fig. 1). Wart-like growths were seen as reminiscent of a cauliflower in or around the mouth, buccal mucosa, tongue and gingiva. The dog had such a large number of papillomas that consuming food became a problem.

A tentative diagnosis of canine oral papillomavirus (PV) infection was made on the gross appearance of the numerous lesions. Two warts from the oral mucosa were removed surgically for further diagnostic investigations. The diagnosis was established by histological examination in association with immunohistochemical analysis.

Wart specimens were fixed in 10\% neutral-buffered formalin solution, and then embedded in paraffin following the routine processing. Five- $\mu \mathrm{m}$-thick sections obtained from the paraffin blocks were stained with haematoxylineosin. For immunohistochemistry, sections were prepared using a commercial avidin-biotin peroxidase complex (ABPC) kit (Zymed Laboratories, Inc., CA). Firstly, deparaffinized sections were quenched for endogenous peroxidase with $3 \% \mathrm{H}_{2} \mathrm{O}_{2}$ in phosphate-buffered saline (PBS), and then exposed to anti-PV genus specific antigen

Address for correspondence:

Assoc. Prof. H.S. Biricik

Department of Surgery

Faculty of Veterinary Medicine

Harran University

Phone: +90 4143128456

Fax: +90 4143144158

E-mail: hsbiricik@yahoo.com

Sanlıurfa, Turkey

http://www.vfu.cz/acta-vet/actavet.htm 
(PVGA) antibody (DAKO, Carpinteria, CA). The sections were incubated with biotinylated anti-mouse secondary antibody, followed by streptavidin-peroxidase conjugate, and then treated with 3-amino-9-ethylcarbozale (Zymed Laboratories, Inc., CA) and counterstained with Mayer's haematoxylin.

Taurolidine (Taurolin, Saba Ilac, Turkey) $45 \mathrm{mg} / \mathrm{kg}$ in Ringer's solution was given intravenously every 3 days through the cephalic vein. We began to observe the regression of papilloma after the first application, with a complete resolution after the fifth application (Plate X, Fig. 2). The dog's appetite improved two days after the first application. Throughout the treatment, firstly the live colour of the warts changed to porcelain white before completely disappearing. While the warts on the tongue rapidly regressed following the third application, those in the gingiva were the most resistant to the therapy, resolving at the fifth application. No side effects were noted during and after taurolidine administration.

Grossly, the lesions were typical papillomas with multiple proliferative, firm, white-gray growths. Histologically, the structure was composed of a very thick squamous epithelium, with hyperkeratosis and thin papillary projections on thin fibrovascular stalks (Plate XI, Fig. 3). Cells in the upper areas of the stratum spinosum had a clear cytoplasm, numerous coarse keratohyaline granules of various sizes, and the epithelium did not include intranuclear inclusions. Additionally, individual cells in the hyperplastic epithelium were swollen with a clear cytoplasm and a large, round to oval vesicular nucleus (koilocytes). The nuclei of some cells in the granular layer were stained positively for PVGA by the ABPC method (Plate XI, Fig. 4). In the regressing canine oral warts after taurolidine application, degenerative changes and shorter, rough papillary projections in the squamous epithelium with increased koilocyte atypia, submucosal numerous mononuclear infiltration and few neutrophils were observed (Plate XII, Fig. 5). There were still a small number of positively immunostained nuclei for PVGA in the epithelium. No papillomas reoccurred in the treated dog.

\section{Discussion}

Not all lesions diagnosed as papillomas in animals are caused by or contain PV. Our findings are consistent with previous reports of using histological and immunohistochemical means to screen for PV infections (Campbell et al. 1988; Sundberg et al. 1984, 2000). Most mucosal lesions were relatively flat and characterized by productively infected keratinocytes degenerating into koilocytes. These features are characteristic of the general cytopathic effect of papillomavirus infections. In papillomas, true PV inclusions are seldom seen in paraffin-embedded sections of natural disease (Sundberg et al. 2000). In the present case, intranuclear inclusions were not seen; however, papillomavirus structural antigens were detected by an immunoperoxidase technique in many koilocytes.

Viral papillomas should disappear naturally as the dog's immune system matures and generates a response against the papillomavirus (Nicholls et al. 1999, 2001). Typically, it takes 1-5 months for papillomas to regress with oral growths tending to regress sooner than ocular growths; therefore, food consumption becomes a problem. To resolve the disease, electrocautery, surgical crushing of warts (to stimulate immunity), oral interferon, oral levamisole, intravenous immunoregulin, intravenous vincristine, and subcutaneous vaccination with an autogenous vaccine derived from homogenised warts have been used (Nicholls et al. 1999).

Jacobi et al. (1997) reported that intraperitoneal taurolidine inhibits the adherence of colon tumour cells injected into peritoneal cavity of rats. More recent evaluations of taurolidine have shown significant antineoplastic activity in several human tumour cell lines (Da Costa et al. 2001). This compound is non-toxic and free from side effects following intravenous (i.v.) and intraperitoneal (i.p.) administration (Jurewitsch et al. 1998; Johnston et al. 1993). The lack of significant toxicities makes taurolidine a very attractive candidate for use as an antineoplastic agent (Nici et al. 2004; Torres-Viera et al. 2000; Braumann et al. 2006). It has also been shown to inhibit the growth of human ovarian, colon and prostate tumour cells (Shrayer et al. 2003).

As a result, taurolidine seems to be effective in the treatment of canine oral papillomatosis. To the authors' knowledge, this is the first report examining taurolidine's activity against canine oral papillomatosis. Obviously, further studies need to be undertaken on the effect of taurolidine. 


\section{Orální papilomatóza u psa a její léčba taurolidinem}

Byla vyhodnocována účinnost taurolidinu v rámci léčby orální papilomatózy u jednoletého anatolského pasteveckého psa. Diagnóza papilomatózy byla stanovena na základě klinických příznaků a výsledků histopatologického a imunohistochemického vyšetření. Psovi bylo každé 3 dny i.v. podáno $45 \mathrm{mg} \cdot \mathrm{kg}^{-1}$ taurolidinu. Regrese papilomů byla pozorována po zahájení léčby, a po páté aplikaci vymizely.

\section{Acknowledgement}

The authors would like to thank Dr. Halit Oguz for his valuable comments during the study.

\section{References}

BLENKHARN JI 1988: Sustained anti-adherence activity of taurolidine (Taurolin) and noxythiolin (Noxyflex S) solutions. J Pharm Pharmacol 40: 509-511

BRAUMANN C, WINKLER G, ROGALLA P, MENENAKOS C, JACOBI CA 2006: Prevention of disease progression in a patient with a gastric cancer-re-recurrence. Outcome after intravenous treatment with the novel antineoplastic agent taurolidine. Report of a case. World J Surg Oncol 4: 34

BREDAL WP, THORESEN SI, RIMSTAD E, ALEKSANDERSEN M, NAFSTAD PH 1996: Diagnosis and clinical course of canine oral papillomavirus infection. J Small Anim Pract 37: 138-142

CAMPBELL KL, SUNDBERG JP, GOLDSCHMIDT MH, KNUPP C, REICHMANN ME 1988: Cutaneous inverted papillomas in dogs. Vet Pathol 25: 67-71

DA COSTA ML, REDMOND HP, BOUCHIER-HAYES DJ 2001: Taurolidine improves survival by abrogating the accelerated development and proliferation of solid tumors and development of organ metastases from circulating tumor cells released following surgery. J Surg Res 101: 111-119

FENNER F, GIBBS EPJ, MURPHY FA, ROTT R, STUDDERT MJ, WHITE DO 1993: Veterinary Virology. $2^{\text {nd }}$ ed. Academic Press, London, $666 \mathrm{p}$.

JACOBI CA, ORDEMANN J, BOHM B, ZIEREN HU, SABAT R, MULLER JM 1997: Inhibition of peritoneal tumor growth and implantation in laparoscopic surgery in a rat model. Am J Surg 174: 359-363

JOHNSTON DA, PHILIPS G, PERRY M, MCALPINE H, RICHARDS J, PENNINGTON CR 1993: Taurolidine for the prevention of parenteral nutrition related infection: antimicrobial activity and long-term use. Clin Nutr 12: $365-368$

JUREWITSCH B, LEE T, PARK J, JEEJEEBHOY, K 1998: Taurolidine 2\% as an antimicrobial lock solution for prevention of recurrent catheter-related bloodstream infections. J Parenter Enteral Nutr 22: 242-244

McCOURT M, WANG JH, SOOKHAI S, REDMOND HP 2000: Taurolidine inhibits tumor cell growth in vitro and in vivo. Ann Surg Oncol 7: 685-691

NICHOLLS PK, KLAUNBERG BA, MOORE RA, SANTOS EB, PARRY NR, GOUGH GW, STANLEY MA 1999: Naturally occurring, nonregressing canine oral papillomavirus infection: host immunity, virus characterization, and experimental infection. Virology 20: 365-374

NICHOLLS PK, MOORE PF, ANDERSON DM, MOORE RA, PARRY NR, GOUGH GW, STANLEY MA 2001: Regression of canine oral papillomas is associated with infiltration of CD4+ and CD8+ lymphocytes. Virology 25: 31-39

NICI L, MONFILS B, CALABRESI P 2004: The effects of taurolidine, a novel antineoplastic agent, on human malignant mesothelioma. Clin Cancer Res 10: 7655-7661

SHRAYER DP, LUKOFF H, KING T, CALABRESI P 2003: The effect of Taurolidine on adherent and floating subpopulations of melanoma cells. Anticancer Drugs 14: 295-303

SUNDBERG JP, JUNGE RF, LANCASTER WD 1984: Immunoperoxidase localization of papillomaviruses in hyperplastic and neoplastic epithelial lesions of animals. Am J Vet Res 45: 1441-1446

SUNDBERG JP, VAN RANST M, MONTALI R, HOMER BL, MILLER WH, ROWLAND PH, SCOTT DW, ENGLAND JJ, DUNSTAN RW, MIKAELIAN I, JENSON AB 2000: Feline papillomas and papillomaviruses. Vet Pathol 37: 1-10

TORRES-VIERA C, THAUVIN-ELIOPOULOS C, SOULI M, DeGIROLAMI P, FARRIS MG, WENNERSTEN CB, SOFIA RD, ELIOPOULOS M 2000: Activities of taurolidine in vitro and in experimental enterococcal endocarditis. Antimicrob Agents Chemother 44: 1720-1724 

Plate X

Biricik H.S. et al.: Oral papillomatosis ... pp. 373-375

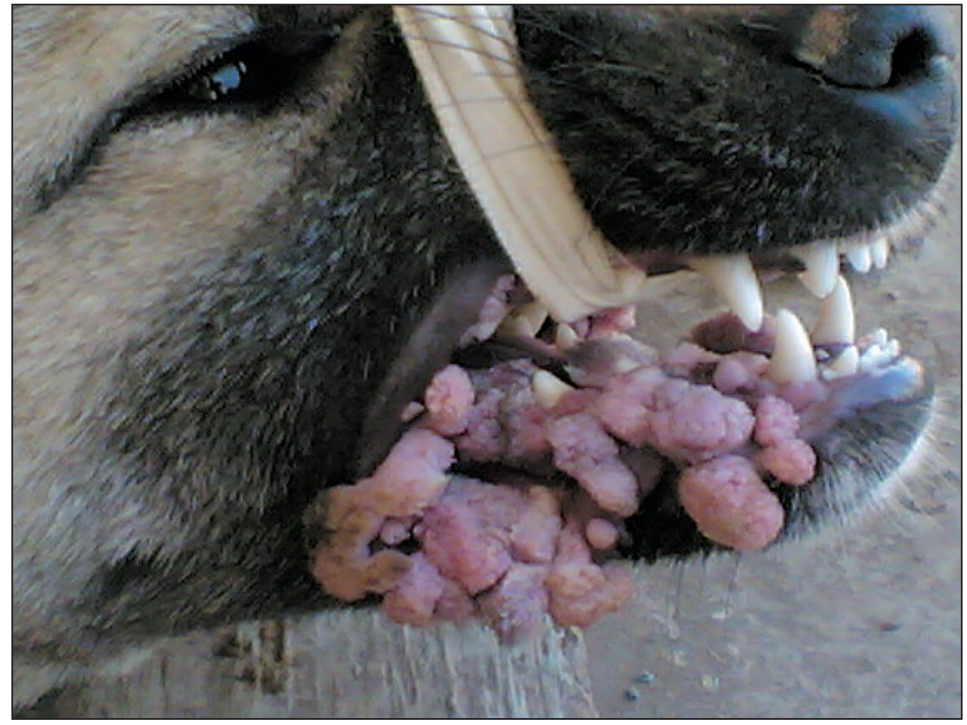

Fig. 1. Appearance of the patient before treatment

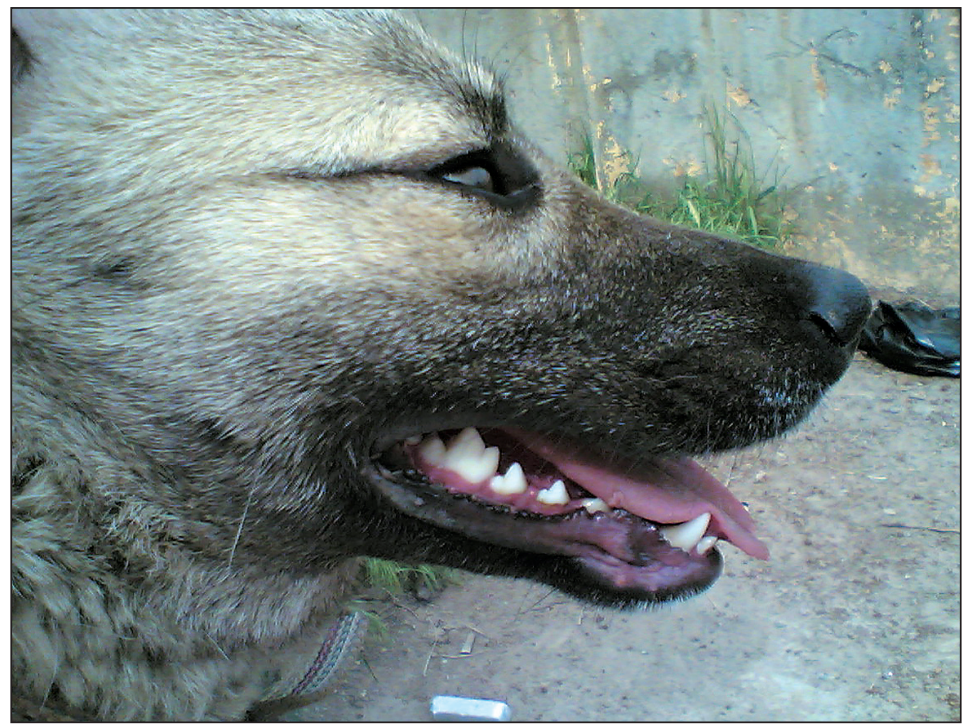

Fig. 2. Complete regression of papillomas after the fifth application 


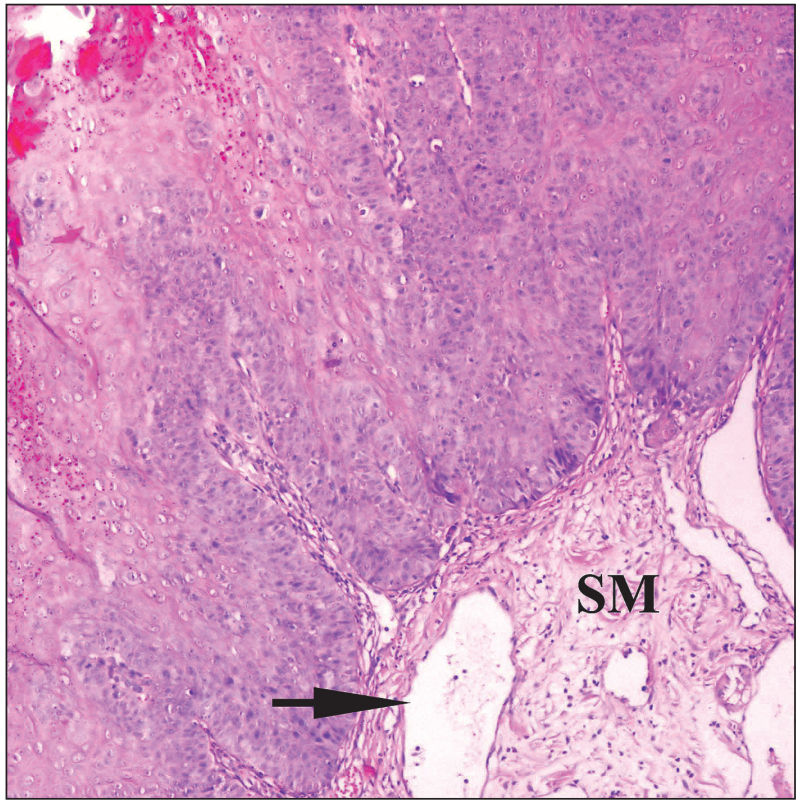

Fig. 3. Microscopic appearance of the patient before treatment. The hyperplastic epithelium with hyperkeratosis. Arrow indicates a dilated vascular structure. SM = submucosa. $\mathrm{HE}, \times 120$

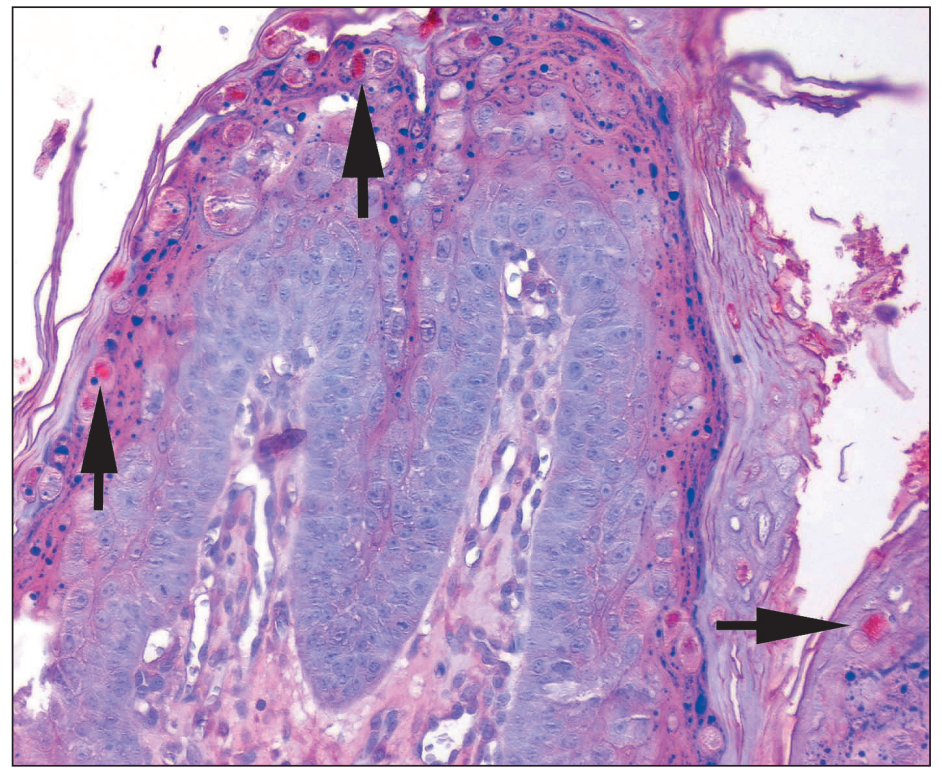

Fig. 4. Immunostaining of papillomavirus antigen in nuclei of epithelium in the regressing wart. ABPC method, AEC chromogen, Mayers' haematoxylin counterstain, $\times 120$ 


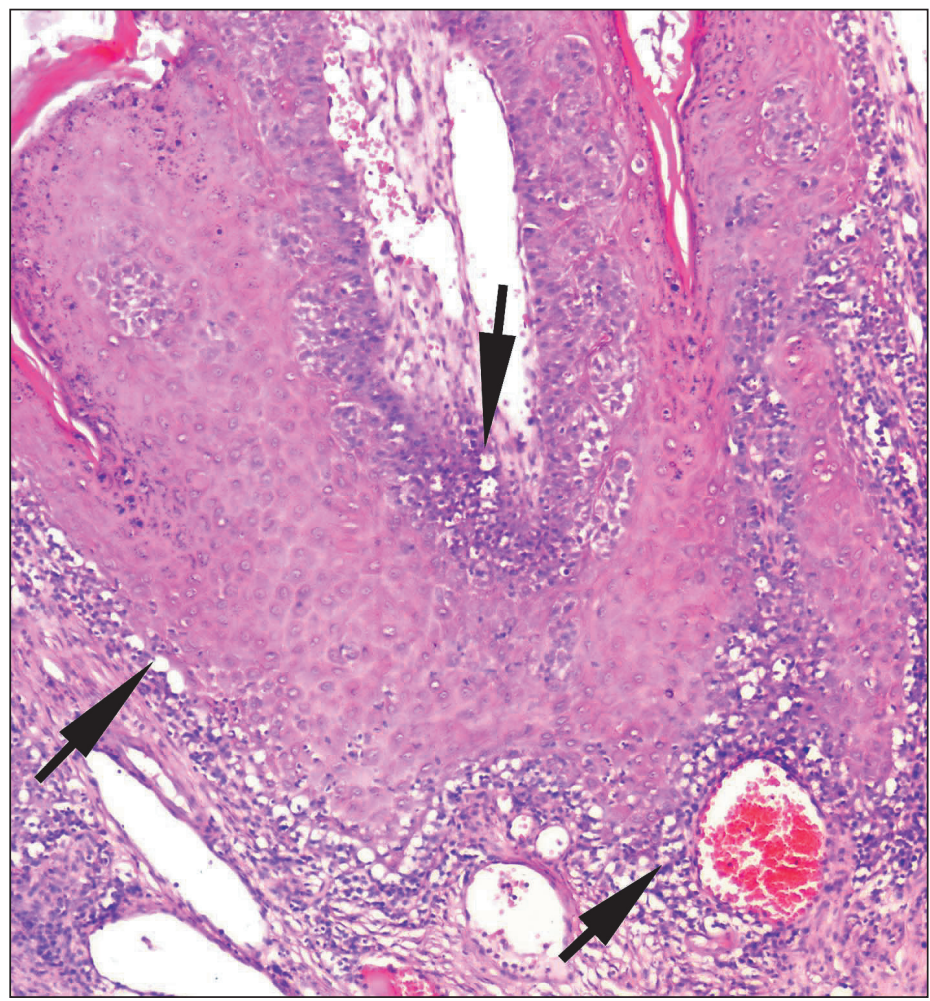

Fig. 5. Regressed papillomas after the treatment. Note the degenerative changes (arrows) in the squamous epithelium and the presence of dense inflammatory cells under the epithelium. $\mathrm{HE} \times 120$ 